\title{
Impulse Buying Model for Business-to-Consumer E-Commerce in Saudi Arabia
}

\author{
Ibtisam M. Arrafi, Fahad M. Ghabban \\ Information System Department, Taibah University, Madinah, Saudi Arabia \\ Email: Fghaban@taibahu.edu.sa
}

How to cite this paper: Arrafi, I. M., \& Ghabban, F. M. (2021). Impulse Buying Model for Business-to-Consumer E-Commerce in Saudi Arabia. iBusiness, 13, 81-102. https://doi.org/10.4236/ib.2021.132006

Received: March 13, 2021

Accepted: April 13, 2021

Published: April 16, 2021

Copyright (๑) 2021 by author(s) and Scientific Research Publishing Inc. This work is licensed under the Creative Commons Attribution International License (CC BY 4.0).

http://creativecommons.org/licenses/by/4.0/

\begin{abstract}
E-commerce has been growing rapidly worldwide, and with the current COVID pandemic, consumers are relying on it. In Saudi Arabia, the online shopping has been improving but it has not reached its full potential. That is why the concept of Impulse buying is essential and should be applied in the Saudi e-commerce. Therefore the purpose of this research paper is to identify and analyse the factors that affect impulse buying, specifically the Business-to-Consumer type, in Saudi Arabia and how to improve the e-commerce sector. This study is done using a quantitative approach to achieve the purpose of this study. There were 290 respondents, (81.9\%) respondents were female and (18.1\%) respondents were male. The respondents were familiar with e-commerce and the definition of the IB, however, the majority had a minimum knowledge regarding the effect that IB can create to their purchase decisions. A quantitative approach was a suitable choice for deductive methods since the results can be used to be generalized on a larger population. A questionnaire-based survey was used to collect the data for finding relationships between the indicators and factors. It was found out that advertisement, impulsiveness, and promotion are the main factors that positively influence IB in Saudi Arabia, but the factors of income and comment did not have any effect on IB.
\end{abstract}

\section{Keywords}

E-Commerce, Saudi Arabia, Impulse Buying, Advertisement, ICT

\section{Introduction}

Electronic commerce (e-commerce) has been developing to be the new major means of exchange products and services between customers and market. Espe- 
cially, with the current COVID pandemic, e-commerce has experienced a rapid growth since March (United Nations). Businesses can increase their sales by using e-commerce, especially small businesses. They can advertise their products and services online to the virtual community around the world. E-commerce is simply exchanging goods and services online using the internet between two main parties: Businesses and Consumers. The number of Businesses joining the e-commerce sector has rapidly grown to offer online shopping as a new method of shopping. According to United Nations, the Third-party online marketplaces have increased their sales after joining e-commerce by 35\% (United Nation). As the online shopping industry is dominating and keeping up with fashion and brand choice, the number of stores and shopping malls has decreased in the last few years. Customers have more variety from the online shopping malls comparing to the small stores (Akram et al., 2017).

E-commerce is categorized into four types based on the relationship between the two parties of reciprocity. There are Business to Consumer (B2C), Business to Business (B2B), Consumer to Consumer (C2C) and Consumer to business (C2B) (Nanehkaran, 2013).

When talking about online shopping, the concept of impulse buying is important to discuss. It refers to any purchases that may be unplanned or sudden as they are usually originated on the spot and are highly correlating with strong willingness and sensations of delight and provocation $(\mathrm{Wu}, \mathrm{Chen}, \&$ Chiu, 2016). Purchasing products online is more convenient to many customers. Placing orders with one click, getting all the information about the products, having access to all the products, and delivery time are all major factors which lead to buying impulsively online. The vast growth of e-commerce and development of Information Technology helps to make IB prevalent. If online retailers have a better understanding of the factors that encourage online IB, especially in the $\mathrm{B} 2 \mathrm{C}$ relationship, there will be a significant increase in the purchases of online industry (Harmancioglu, Finney, \& Joseph, 2009).

According to Rahman, many research papers have proven that there is a high percentage of impulsive buying, which accounts $62 \%$ of supermarket sales and $80 \%$ of all sales in certain categories of products (Rahman, 2015). However, Saudi Arabia is still struggling with the growth of e-commerce comparing with its fast economy prosperity (Makki \& Chang, 2014). The limitations of e-commerce lead to lack of knowledge about IB and its advantages of e-commerce.

With regard to IB's important role in consuming markets and market economy and results, and consuming market evaluation, there is a clear lack of awareness of retailers and sellers about IB, and tools of appropriate use of selling progress are clearly distinguishable by pushing buyers for more consumer market boom as a problem in consuming market especially retailers and sellers. Considering this reality, therefore, that IB is a high percentage of shop purchases, it is necessary to recognize and study effective variable on these purchases until the boom of consumer markets and market economy remains effective. This study will find IB factors for B2C that influence consumers to involve in IB. 
This study will propose a model, which combines IB factors that influence consumer to buy impulsively, and the result of this study could help marketers in Saudi Arabia to better understand IB factors that influence consumers to buy impulsively to increase their income.

Recent researches are more concentrating on IB in physical stores. While others are focusing on limited factors of IB, there is the need of IB factors in B2C e-commerce in Saudi Arabia. Therefore, this study attempts to propose impulse buying model for $\mathrm{B} 2 \mathrm{C}$ e-commerce. The main research question for this study is How to develop an IB model of B2C e-commerce for Saudi Arabia?

Therefore, this research paper addresses the limitations of IB and determines the IB factors that affect customers to purchase impulsively in online shopping in Saudi Arabia. Also, this research paper studies a new model of IB for B2C e-commerce based on the identified IB factors and evaluates the effectiveness of the proposed model in Saudi Arabia.

\section{Literature Review}

E-commerce has made the reciprocity of goods and services more convenient for the market sector. It is considered important because it is adapting the current IT and communication. These days, e-commerce is dominating over the traditional commerce causing shopping malls and stores to shut down. Customers have the ability to choose and order products on websites wherever they are on virtual networks and get their purchases in front of their houses within a few days.

According to (Britannica, 2020), the definition of E-commerce, in full electronic commerce, is "maintaining relationships and conducting business transactions that include selling information, services, and goods by means of computer telecommunications networks". It has four major types: Business-to-Business (B2B), Business to Consumer (B2C), Consumer-to-Consumer (C2C) and Consumer to business (C2B). Business to Business deals between businesses or a transaction that occurs among companies to convey services and goods, such as online wholesaling. Consumer to Business is trading goods or services from individuals to businesses. Consumer-to-Consumer is involving two users or customers conducting transactions between each other. The last one is Business-to-Consumer. Other types of e-commerce include Business-to-Government (B2G), where businesses whose clients are governments or type of public administration, and Consumer-to-Government, where individuals pay taxes to the government or tuitions to colleges (DeMatas, 2019).

The dominant type of e-commerce is Business-to-Consumer, which refers to transactions, including products and services, occur from the market to consumers. It also refers to online businesses and auctions, such as online stock trading markets, and online auction for different goods. B2C is an online business model where all the transactions happen online via the internet. The main advantage of B2C e-commerce is that it creates a virtual store for customers with minimal capital. Other advantages are providing flexibility, easy communication 
and fast delivery, and wide variety of items (Mirescu, 2010). The following Figure 1 shows the relationship between consumers and Businesses in the $\mathrm{B} 2 \mathrm{C}$ model (Abumalloh, Ibrahim, \& Nilashi, 2020).

\section{Impulse Buying}

Foremost, researchers were concerned in comprehending impulse buying. Researchers have put a lot of effort into defining this complex and interesting concept. Many researchers have suggest difference conceptual definitions of impulse buying, unplanned and sudden are the major key words in impulse buying definition (Harmancioglu et al., 2009). IB is an unplanned buying decision, made unexpectedly before purchasing a product or service. Rook defined impulse buying as a sudden, usually potent and permanent impetus to purchase something instantly (Rook, 1987). (Karbasivar \& Yarahmadi, 2011) based on Rook, (1987) it is concluded that Individual buying impulses are less probably to take through account the consequences or think carefully before purchasing process.

In order to have more profits for businesses, the concept of impulse buying should be taken into consideration. Researchers have been defining that concept as unplanned or sudden purchases by the customers (Harmancioglu et al., 2009). According to Rook, IB is also defined as "a sudden, usually potent and permanent impetus to purchase something instantly" (Rook, 1987). This concept depends more on the excitement and emotions of the buyers rather than logic. IB eliminates the idea of thinking carefully before purchasing items and putting in the buyer's mind that they need the item (Rook, 1987). There are four different types of IB: Pure Impulse Buying, Reminder Impulse Buying, Suggestion Impulse Buying, and Planned Impulse Buying (Hosseini, Zadeh, Shafiee, \& Hajipour, 2020). The following Figure 2 shows the order of the four types in terms of emotional appeal (Altaf, Shamim, Yousaf, \& Ghazali, 2013).

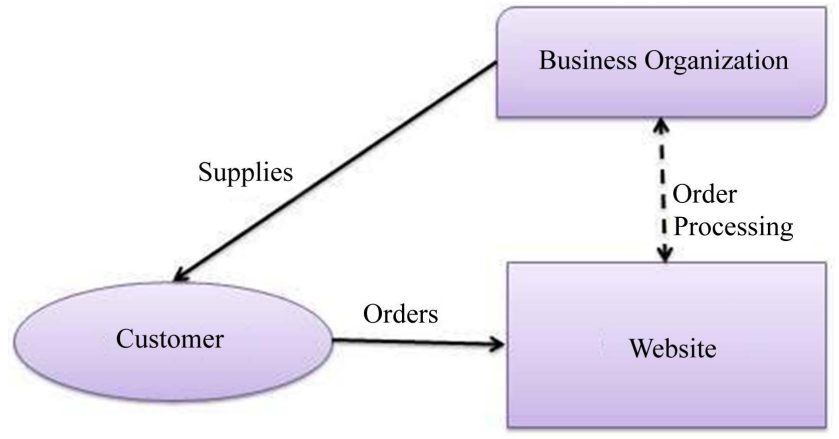

Figure 1. B2C business model.

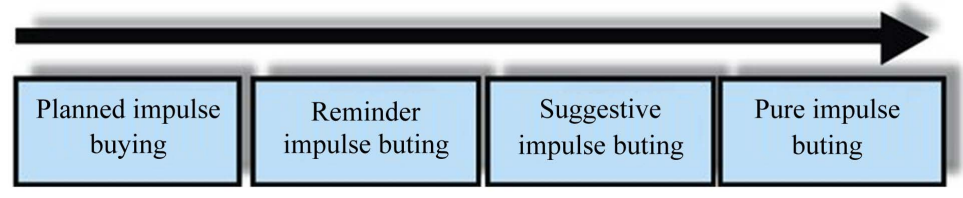

Figure 2. IB types from least to most level of emotional appeal. 


\section{Impulse Buying Classification}

By identifying the different types of IB behaviour, the understanding of impulse buying has also been improved. Many factors influenced Impulse buying such as personality traits, website quality and promotion. (Amiri, Jasour, Shirpour, \& Alizadeh, 2012) there are four categorizations of impulse buying according to (STERN, 1962):

1) Pure Impulse Buying. The pure impulse purchase is the most easily eminent form of IB. This is impulsive purchasing, the purchase of novelty or escape that breaks a normal style of buying.

2) Reminder Impulse Buying. Reminder impulse buying happens when buyers see the products and recalls that the inventory is exhaustive at home. The main factor is remembered knowledge of the good that "sparks" the purchase of the impulse.

3) Suggestion Impulse Buying. Suggestion buying happens when customers first see goods and conceives a need for it, although they have no prior knowledge of the products. Item fineness, function, and the like should be evaluated at the moment of buying.

4) Planned Impulse Buying. It may imitate irregular, it is precise. Planned impulse buying happens when the buyers' login to the web with some buying thoughts, but with the animus to do other buy that rely on offers, low cost and the desire.

All types mentioned previously are from cognitive of consumers about products. While suggestion impulse buying is completely without previous knowledge of the items and without any previous plan to buy, which is the researcher selection as criteria in this study, the planned impulse buying happen with pre plan to buy. Author focuses on the suggestion impulse buying as more type of IB is related to online IB. According to suggestion impulse buying definition, all factors that fall under this type could classify as an IB factors.

According to (Mathur, 2019; Muruganantham \& Bhakat, 2013), Pure impulse buying is escape purchase which a shopper breaks the trend of usual shopping, Reminder impulse buying is when the buyer is reminded of the need of the product during the shopping process, suggestion impulse purchase is the purchase of new products depending on self-suggestion but without any prior intention, and Planned impulse buying is partially planned but specific product or categories are not decided by the shopper (Mathur, 2019; Muruganantham \& Bhakat, 2013).

E-commerce in Saudi Arabia has been growing rapidly over the past few years (Alshehri, 2015). In 2014, the online sales in the Middle East reached around 7 billion dollars, including $\$ 1.5$ billion from Saudi Arabia. In 2017, the total e-commerce sales reached $\$ 3.076$ billion in Saudi Arabia, and it is expected to grow to $\$ 9.41$ billion by 2021 (Nordea, 2021). There are several factors for predicting this growth; Saudi Arabia has a strong underlying economic growth, raise the concept of modern retailing, and change some of the cultural concepts 
like improving the position of women in society. According to (Rahman, 2016), the Saudi buyers have shown the use of the IB when purchasing. They tend to buy impulsively and go to other products if their preference is not in stock (Rahman, 2015).

However, the growth expected from researchers is still higher than the current one. According to (Statista, 2021), the total revenue of e-commerce in Saudi Arabia in 2020 is $\$ 6.328$ billion, and the expected revenue in 2021 is only $\$ 7.051$ billion. There was a significant revenue increase from 2019, however it was only due to COVID pandemic (Statistia).

E-commerce in Kingdome of Saudi Arabia is developing and expanding quickly and B2C e-commerce grows rapidly. (Alshehri, 2015) expected that Saudi merchandising revenues will grow from $\$ 76.7$ billion in 2011 to almost $\$ 117$ billion in 2015. The main reasons for this predicted growth in Kingdome of Saudi Arabia's 14 retail sales are: "strong underlying economic growth, rising disposable incomes, increasing acceptance of the concept of modern retailing, a youthful population and an enlarged consumer base created by the improved position of women in society". The below chart Figure 3 shows the increase in the revenue of e-commerce and the predicted ones for the next 4 years (Statista, 2021).

Researchers argue that the reason behind this decay is due to several factors that affect the e-commerce IB. There are two kinds of factors: External and Internal. Those factors can affect the people to buy online. For example, the needs for goods is one of the important factors to enhance the online buying. The following Figure 4 shows the relationship between those factors and how they trigger to buy impulsively (Wang, Tauni, Zhang, Ali, \& Ali, 2020).

Revenue

10000

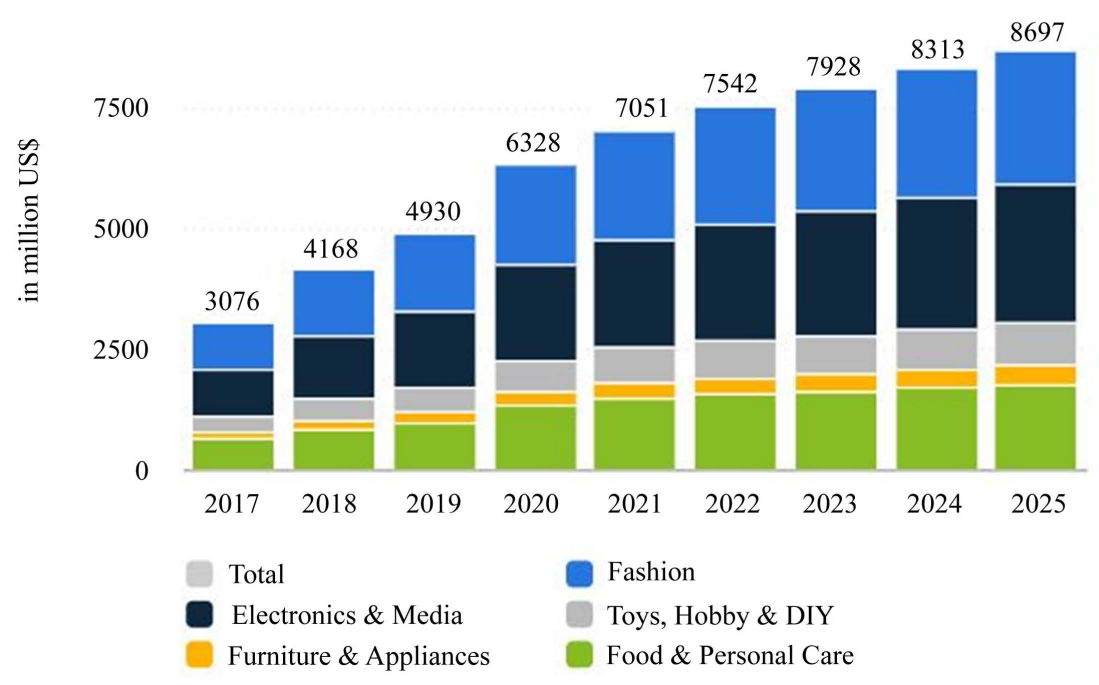

Figure 3. Total revenue of e-commerce from 2017-2025 in Saudi Arabia (Statista, 2021). 


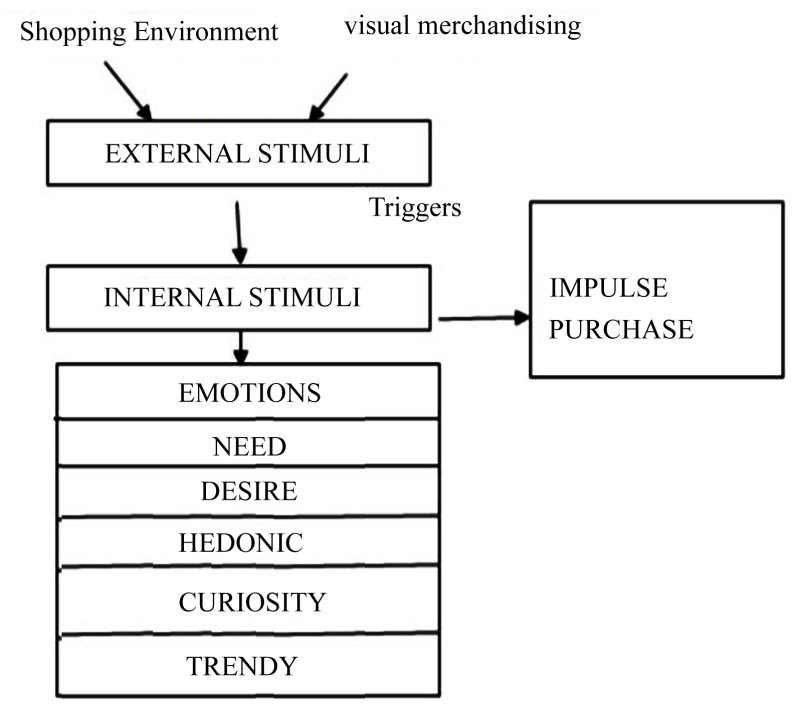

Figure 4. External and Internal factors that affect IB (Wang, Tauni, Zhang, Ali, \& Ali, 2020).

Many research papers focus on emotions when talking about IB. Emotions have a major impact on the decision that the consumer makes in the shopping process. (Choudhary, 2014) came up with a theory that emotions have a major role in IB. Retailers are aware of that, and they try their best to accommodate the consumer's feelings (Choudhary, 2014). Buying helps customers to combat insecurity and give them a sense of completeness. According to (Chang, Eckman, \& Yan, 2011), Customers with more positive emotional reactions were more likely to do IB in the retail environment (Chang et al., 2011). In addition to that, the mood of the consumer certainly affects their decision while shopping. Excitement and happiness certainly help in encouraging IB, and therefore, increase the revenue of e-commerce.

\section{Potential Factors}

There are several factors that can affect IB, and therefore, affecting the purchase decision of the consumers. Consumers with a high level of impulsiveness are influenced by the graphics and design of online shopping websites leading them to impulsively buy more items. The following Table 1 shows all the factors from previous studies that influence IB in the Business-to-Consumer type.

\section{Extract Factor}

According to Table 1, the factors of gender and age were used in 3 different studies, while the income factor was used in 4 studies. The other factors that were used in 4 studies were comments, advertisements, and customer's impulsiveness. Furthermore, the promotion factor was used in five different studies. Therefore, the selected factors for this study are promotion, impulsiveness, advertisement, income, and comments. The following Table 2 shows in details the factors that affect IB and their definitions. 
Table 1. List of IB factor with their definitions.

\begin{tabular}{|c|c|c|}
\hline Factors & Definition & Reference \\
\hline Gender & $\begin{array}{l}\text { Women buy different types of products on } \\
\text { impulse compared to men and purchase } \\
\text { more effectively than men }\end{array}$ & $\begin{array}{l}\text { (Awan \& Abbas, 2015), } \\
\text { (Merugu \& Vaddadi, 2017) }\end{array}$ \\
\hline Age & $\begin{array}{l}\text { Consumers from variety age buy } \\
\text { impulsively differently. }\end{array}$ & $\begin{array}{l}\text { (Yang, Huang, \& Feng, 2011), } \\
\text { (Merugu \& Vaddadi, 2017), }\end{array}$ \\
\hline Income & $\begin{array}{l}\text { The availability of cash is a facilitator } \\
\text { in the IB system as it speeds up the } \\
\text { individual's purchasing power. If the } \\
\text { customers have insufficient money, } \\
\text { they will completely avoid the shopping } \\
\text { environment }\end{array}$ & $\begin{array}{l}\text { (Yang et al., 2011), } \\
\text { (Merugu \& Vaddadi, 2017), } \\
\text { (Tinne, 2011) }\end{array}$ \\
\hline Education & $\begin{array}{l}\text { The level of education is affected on } \\
\text { consumers who buy impulsively. }\end{array}$ & (Yang et al., 2011) \\
\hline Emotions & $\begin{array}{l}\text { The part of the character of a person that } \\
\text { consists of his feelings as opposed to his } \\
\text { thoughts. Positive or negative consumers' } \\
\text { emotions could effect on impulse buying. }\end{array}$ & $\begin{array}{l}\text { (Chang et al., 2011), } \\
\text { (Choudhary, 2014), } \\
\text { (Piyush Sharma, Sivakumaran, } \\
\text { \& Marshall, 2009) }\end{array}$ \\
\hline Self-esteem & $\begin{array}{l}\text { Satisfying the desires, gaining others' } \\
\text { respect }\end{array}$ & $\begin{array}{l}\text { (Saad \& Metawie, 2015), } \\
\text { (Harmancioglu et al., 2009) }\end{array}$ \\
\hline Excitement & Enjoying and having fun & $\begin{array}{l}\text { (Harmancioglu et al., 2009), } \\
\text { (Saad \& Metawie, 2015) }\end{array}$ \\
\hline Impulsiveness & $\begin{array}{l}\text { Experience spontaneous and sudden } \\
\text { impetus to make on - the-spot purchases } \\
\text { and behave with little (conscious) } \\
\text { consequence conference on these felt urges. }\end{array}$ & $\begin{array}{l}\text { (Piyush Sharma et al., 2009), } \\
\text { (Chang et al., 2011), } \\
\text { (Kem Z.K. Zhang, Xu, Zhao, } \\
\text { \& Yugang Yu, 2018), } \\
\text { (Wells, Parboteeah, } \\
\text { \& Valacich, 2018) }\end{array}$ \\
\hline $\begin{array}{l}\text { Website } \\
\text { quality }\end{array}$ & $\begin{array}{l}\text { The level of trust in website, safety and the } \\
\text { design of website }\end{array}$ & $\begin{array}{l}\text { (Wells et al., 2018), } \\
\text { (Dawson \& Kim, 2009), } \\
\text { (Veena Parboteeah, 2009) }\end{array}$ \\
\hline Promotion & $\begin{array}{l}\text { Group of different motivational tools, is } \\
\text { originated to trigger customers to buy } \\
\text { abundant goods or services within short } \\
\text { periods of time }\end{array}$ & $\begin{array}{l}\text { (Chen \& Wang, 2016), } \\
\text { (Liao, Shen, \& Chu, 2009), } \\
\text { (Yang et al., 2011), } \\
\text { (Merugu \& Vaddadi, 2017) }\end{array}$ \\
\hline $\begin{array}{l}\text { Shopping } \\
\text { with others }\end{array}$ & Shopping with friends, family or peers & (Yu \& Bastin, 2010) \\
\hline $\begin{array}{l}\text { Comments } \\
\text { and reviews }\end{array}$ & $\begin{array}{l}\text { Online reviews indicate to any positive } \\
\text { or negative online customers comments } \\
\text { about goods to encourage customers to } \\
\text { purchase particular items }\end{array}$ & $\begin{array}{l}\text { (Chen, 2012), } \\
\text { (Tinne, 2011), } \\
\text { (Kem, Zhang et al., 2018), } \\
\text { (Chen \& Li, 2009) }\end{array}$ \\
\hline Advertisements & $\begin{array}{l}\text { Advertising is an effective tool to catch } \\
\text { people attention and to convert their } \\
\text { behavior positively toward items. } \\
\text { Advertisement convinces consumers to } \\
\text { use product at least once in their lives }\end{array}$ & $\begin{array}{l}\text { (Abayi \& Khoshtinat, 2016), } \\
\text { (Malik, Ghafoor, \& Iqbal, 2013), } \\
\text { (Taush, 2007) }\end{array}$ \\
\hline
\end{tabular}


Table 2. External factors that affect IB.

\begin{tabular}{cl}
\hline \multicolumn{1}{c}{ Factors } & \multicolumn{1}{c}{ Definition of factor } \\
\hline Promotion & $\begin{array}{l}\text { group of different motivational tools, is originated to influence customers to } \\
\text { buy abundant goods or services within short periods of time without any } \\
\text { prior knowledge of items (Kotler, Keller, Brady, Goodman, \& Hansen, 2012). }\end{array}$ \\
\hline Comments & $\begin{array}{l}\text { online reviews indicate to any positive or negative online customers } \\
\text { comments about new goods to encourage customers to purchase particular } \\
\text { items with no past knowledge of the items (Kem, Zhang et al., 2018). }\end{array}$ \\
\hline Advertisement & $\begin{array}{l}\text { Advertising is an effective tool to catch people attention and to convert their } \\
\text { behavior positively toward items make them involve in impulse purchase. } \\
\text { Advertisement convinces consumers to respond to their urge to buy products } \\
\text { impulsively. (Malik et al., 2013). }\end{array}$ \\
\hline Experience spontaneous and sudden impetus to execute on-the-spot purchases \\
and behave on these felt urges with little (conscious) conference of \\
consequence (Wells et al., 2018) based on (Beatty \& Ferrell, 1987).
\end{tabular}

\section{Research Hypothesis}

Most of the consumer traits as consumer impulsiveness associate with impulse buying. In both online and offline contexts, a consumer's impulsiveness as an individual trait has received considerable attention. Past research found that Impulsiveness is greater driver of impulse buying because it is associated with loss of self-control, premeditation and perseverance, all the integral elements of impulse buying behavior (Piyush Sharma et al., 2009). In an online context, (Wells et al., 2018), (Chen \& Wang, 2016) their research revealed that the individuals with high impulsiveness experience a stronger urge to buy impulsively online compared to individuals with low impulsiveness. Consistent with these findings, a similar relationship should exist between impulsiveness and the Impulse buying in an online context.

$\mathrm{H} 1$ : Consumers' impulsiveness has positive impact in impulse buying in e-commerce.

Advertisement plays a crucial role for any business to boost up its performance graph as it is a powerful strategy to attract customers toward particular product. Online and offline research showed the positive impact of advertisement in customers' buying behaviour. (Malik et al., 2013) found that advertisement has positive impact on consumer buying behaviour and now day's advertisement a big marketing weapon to attract your customers and to stay in customer's mind. (Niazi et al, 2012) revealed that the advertisement play a vital role to attract customer' attention toward the particular product which lead customer to involve in impulse buying. Consumers react to the advertisements are profitable for online shopping. For instance, customers will show more tendency and attention to products through the advertisement. From previous researches, there are good impact of advertisement in buying behaviour whether in offline 
or online, similar relationship should exist between advertisement and impulse buying in an online.

H2: Advertisement has positive impact in impulse buying in e-commerce.

Sales promotion expenditure is a significant basis of marketing spending that deserves more attention from marketers. The main purpose of sales pro-motion is to have an immediate impact on consumers' purchase behaviour. The findings of the (Merugu \& Vaddadi, 2017) study indicate that there is significantly relation between promotional signage and consumer impulsive buying behaviour. Supported previous findings, researcher (Liao et al., 2009) have found the immediate-reward promotion have strong positive impact on impulse buying. When the consumers face promotion situations, the impulse buying is affected and when online stores provide promotions as cash refund, consumers are affected more easily and it increases their continuous impulse buying (Chen \& Wang, 2016). According to previous findings, exist relationship between promotion and impulse buying online is possible.

H3: promotion has positive impact on impulse buying in e-commerce.

The availability of money is a facilitator in the impulse buying process, since it increases the purchasing power of the individual. The income is one of the factors, which play a vital role in influencing the purchasing behaviour of an individual (Figure 5). Many past researchers found that money availability increases the urge to buy impulsively as well as the likelihood of an individual indulging in impulsive purchase (Jyoti \& Verma, 2015) found that money availability have significant positive effect on the construct "urge to buy impulsively" as well as on the construct impulsive buying behaviour. To support that result, (Awan \& Abbas, 2015) found as consumers having more monthly income show more impulse buying behaviour and consumers with low income are less impulsive in their purchase decision. Strong impact of income on impulse buying leads to existence relation between income and impulse buying.

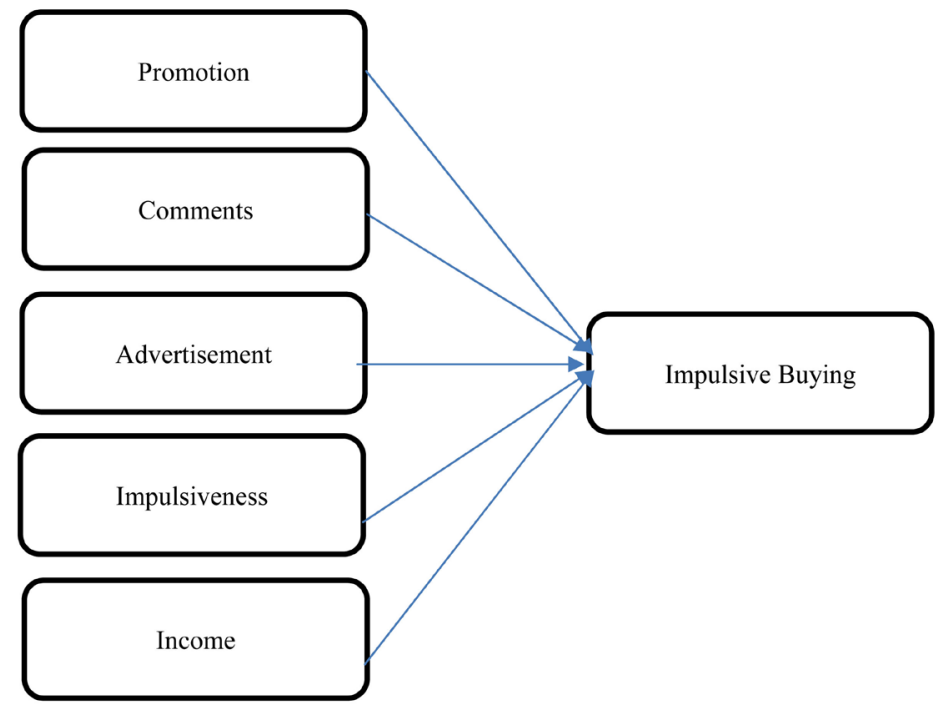

Figure 5. Factors that affect IB. 


\section{H4: Income of consumers has positive impact on impulse buying in} e-commerce.

Online retailers can not only influence consumers by comments, but also can find their shortages and defects in all stages much more easily, and improve their services timely and effectively. Comments and recommendation system has become a part that cannot be missed by any successful online retailer. Some researchers suggest that online consumers can be influenced by comments and recommendation system (Chen, 2012), (Chen et al., 2014). By giving some related and fair information, comment and recommendation systems can give the shopper positive shopping experience and increase the level of purchasing satisfaction. This research provides additional evidence that comments and recommender systems do influence online shopping behaviours and can yield positive outcomes for the firms that implement them (Chen \& Li, 2009).

H5: Comment has positive impact on impulse buying in e-commerce.

\section{Methodology}

There are two research approaches that are mostly used in IS research; quantitative and qualitative approaches. A quantitative approach is used to collate numerical data from an experiment or survey to analyses the concept under investigation. A quantitative approach is a suitable choice for deductive methods, when the study is seeking to generalize the results on a large population. This study used a questionnaire-based survey method in order to collect the data. This study used Partial Least Squares, based on structural equation modelling (PLS-SEM) technique to analyse collected data. PLS-SEM is a well-known multivariate analysis method in the IS research field. According to (Urbach \& Ahlemann, 2010) there are many reasons to choose Smart PLS v3 such as the phenomenon to be investigated is relatively new and measurement models need to be newly developed, the research model is complex with a large number of factors and indicators and relationships between the indicators and factors. In order to develop the questionnaire, the author follows the next stages in the Table 3.

The targeted respondents for this study are purposive who are familiar with online shopping. Therefore, the respondents should know the meaning of IB and

Table 3. Survey development and validation phase.

\begin{tabular}{ccc}
\hline Activities & Objectives & Deliverables \\
\hline $\begin{array}{c}\text { Identify targeted } \\
\text { respondent }\end{array}$ & $\begin{array}{c}\text { To select proper participants that suitable } \\
\text { with the questionnaire }\end{array}$ & $\begin{array}{c}\text { Identified the } \\
\text { data collection }\end{array}$ \\
\hline $\begin{array}{c}\text { Design sampling plan } \\
\text { Develop the } \\
\text { survey instrument }\end{array}$ & To design sampling & Sample size \\
\hline $\begin{array}{c}\text { Face and content } \\
\text { validity of questionnaire }\end{array}$ & $\begin{array}{c}\text { To identify the validity of the questionnaire } \\
\text { face and content by expert review }\end{array}$ & $\begin{array}{c}\text { Developed } \\
\text { questionnaire }\end{array}$ \\
\hline
\end{tabular}


if they buy any product in impulse before. According to the scope of research, the target respondents mostly have knowledge and experience in buying items via online shopping.

This study has selected non-probability sampling for following reasons. First, as the targeted respondent to perform this research was customers who have experience in shopping online and knowledge in the meaning of IB, the number of the population is unknown and cannot be individually identified. Second, access to public individually was not handy, since such procedure would be time consuming.

The researcher used $G^{*}$ power software to calculate the minimum sample size required by this study to ensure adequacy of the sample size in the current study. Using the setting proposed by (Dattalo, 2008) which includes $((\alpha=0.05$ and $\beta=$ $0.80)$ for error type one and two, effect size $=0.15)$ and the number of constructs used in the model ( 6 constructs), the results from $G^{*}$ power software showed that the minimum required number of sample for this study is 98 . This means that the sample obtained in this study by the author was 290 exceeds the minimum sample size required. Therefore, the data collected were sufficient for this analysis to evaluate the model. Figure 6 presents the used of $\mathrm{G}^{*}$.

Next Table 4 present the item generation of the questionnaire which used in this study. It presents the construct, construct definition and reference.

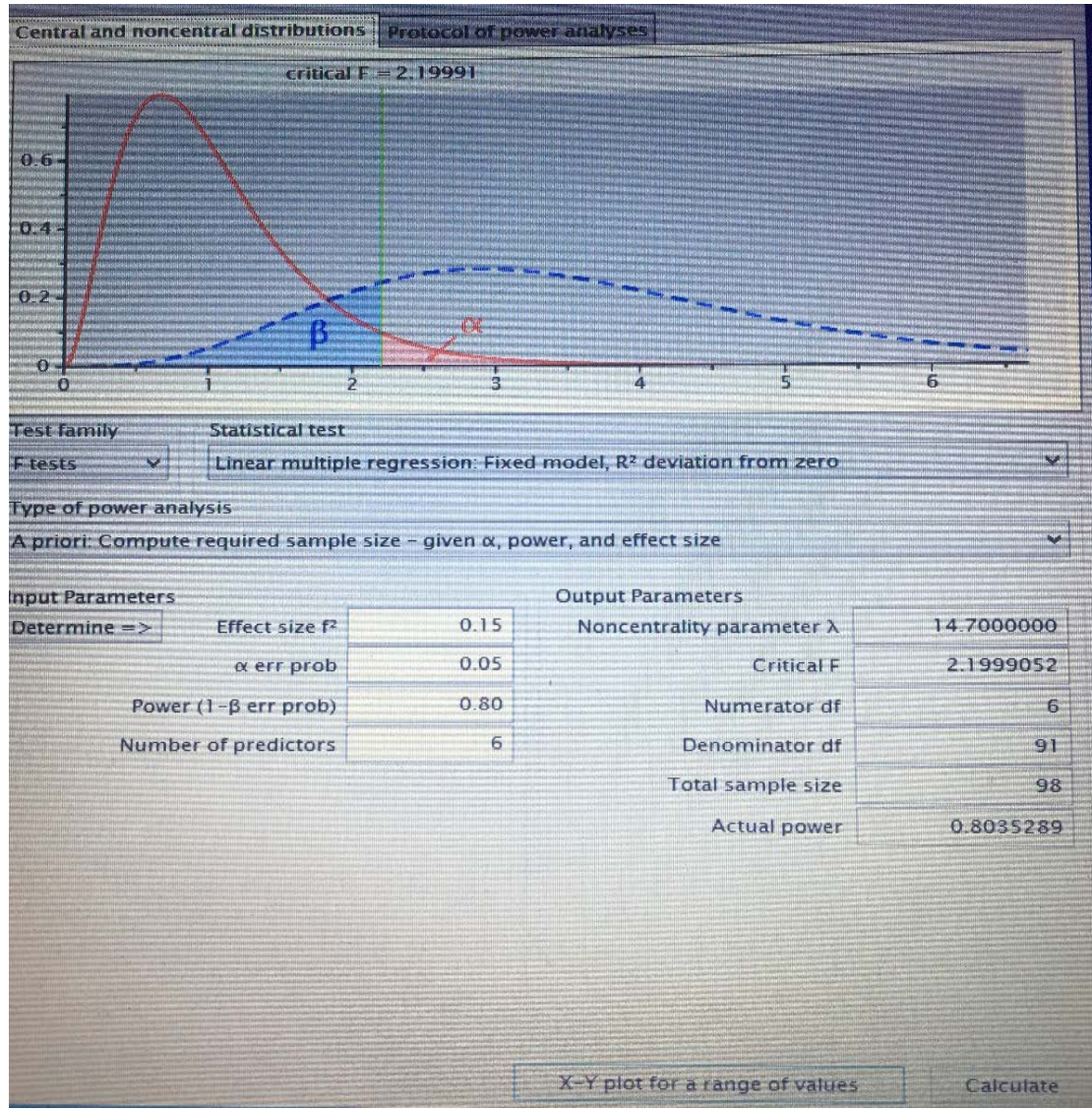

Figure 6. $G^{\star}$ power software result. 
Table 4. Item generation.

\begin{tabular}{|c|c|c|c|}
\hline Construct & Construct definition & Refined item & Adapted from \\
\hline \multirow{3}{*}{$\begin{array}{l}\text { IB for B2C } \\
\text { e-commerce }\end{array}$} & \multirow{3}{*}{$\begin{array}{l}\text { Impulse buying is kind of buying } \\
\text { happened without encompassing } \\
\text { more evaluation of different } \\
\text { stands like affordability, need or } \\
\text { price. }\end{array}$} & $\begin{array}{l}\text { While I surfing online, I } \\
\text { buy new items right away }\end{array}$ & (Koski, 2012) \\
\hline & & $\begin{array}{l}\text { I feel a sense of excitement } \\
\text { when I make an online } \\
\text { impulse buying }\end{array}$ & (KIM, 2003) \\
\hline & & $\begin{array}{l}\text { I involve in impulse } \\
\text { buying regularly }\end{array}$ & (Koski, 2012) \\
\hline Advertisement & $\begin{array}{l}\text { Advertising is an effective tool to } \\
\text { catch people attention and to } \\
\text { convert their behavior positively } \\
\text { toward items. Advertisement } \\
\text { convinces consumers to use } \\
\text { product at least once in their lives } \\
\text { (Malik et al., 2013) }\end{array}$ & $\begin{array}{l}\text { When I visit website based } \\
\text { on internet advertisement } \\
\text { (e.g. Banner ads) that } \\
\text { make me do an impulse } \\
\text { buying } \\
\text { Visiting a website based } \\
\text { on an email advertising } \\
\text { make me involve in an } \\
\text { impulse buying } \\
\text { I often surf the Internet } \\
\text { looking for an attracted } \\
\text { advertisement to do } \\
\text { impulse buying }\end{array}$ & (Koski, 2012) \\
\hline \multirow{2}{*}{ Impulsiveness } & \multirow{2}{*}{$\begin{array}{l}\text { Experience spontaneous and } \\
\text { sudden push to execute buying } \\
\text { and behave on these felt urges } \\
\text { which leads to make impulse } \\
\text { buying with little conscious of } \\
\text { consequence }\end{array}$} & $\begin{array}{l}\text { It is fun to buy things } \\
\text { spontaneously } \\
\text { I don't plan most of my } \\
\text { buying }\end{array}$ & (Koski, 2012) \\
\hline & & $\begin{array}{l}\text { I have difficulty } \\
\text { controlling my urge to } \\
\text { do impulse buying when } \\
\text { I see a good offer }\end{array}$ & (KIM, 2003) \\
\hline \multirow{3}{*}{ Promotion } & \multirow{3}{*}{$\begin{array}{l}\text { Group of different motivational } \\
\text { tools, is originated to trigger } \\
\text { customers to involve in impulse } \\
\text { buying and buy such a good } \\
\text { impulsively }\end{array}$} & $\begin{array}{l}\text { Promotion with free gift } \\
\text { attract me to an } \\
\text { unplanned buying }\end{array}$ & (Koski, 2012) \\
\hline & & $\begin{array}{l}\text { When I see a special } \\
\text { promotion, I involve in } \\
\text { impulse buying } \\
\text { immediately }\end{array}$ & (KIM, 2003) \\
\hline & & $\begin{array}{l}\text { Clearance sale make me } \\
\text { to buying immediately }\end{array}$ & (KIM, 2003) \\
\hline Comments & $\begin{array}{l}\text { Online reviews indicate to any } \\
\text { positive or negative online } \\
\text { customers' comments about } \\
\text { goods to encourage customers } \\
\text { to buying particular items } \\
\text { impulsively. }\end{array}$ & $\begin{array}{l}\text { Customers reviews help } \\
\text { me decide to make an } \\
\text { unplanned buying } \\
\text { decisions when } \\
\text { shopping online } \\
\text { Comments from other } \\
\text { customers makes me do } \\
\text { a buying not planned } \\
\text { Knowing the quantity } \\
\text { left of an item helps me } \\
\text { make my impulse buying } \\
\text { decision. }\end{array}$ & (Koski, 2012) \\
\hline
\end{tabular}


Continued

\begin{tabular}{|c|c|c|c|}
\hline \multirow{3}{*}{ Income } & \multirow{3}{*}{$\begin{array}{l}\text { The availability of money is a } \\
\text { facilitator in the IB process, } \\
\text { since it accelerates the buying } \\
\text { power of the individual }\end{array}$} & $\begin{array}{l}\text { My involving in impulse } \\
\text { buying depends on my } \\
\text { monthly income }\end{array}$ & \multirow{3}{*}{ (Koski, 2012) } \\
\hline & & $\begin{array}{l}\text { The more money means } \\
\text { more buying not planned }\end{array}$ & \\
\hline & & $\begin{array}{l}\text { If I have money I will } \\
\text { buy immediately }\end{array}$ & \\
\hline
\end{tabular}

\section{Results and Discussion}

This study will use SmartPLS2 to analyses the data. The demographic information implicates the information about the buyers, such as gender, age, income, if the customers have past experience in shopping online, if they know the meaning of IB and if they have been involved in IB before.

This study finds the demographic information of respondents. Demographic information implicates the information about the buyers, such as gender, age, income, if the customers have past experience in shopping online, if they know the meaning of IB and if they have been involved in IB before. The previous items are adopted from previous studies. The total number of respondents is $290,(81.9 \%)$ respondents were female and (18.1\%) respondents were male. Next Table 5 describes the demographics of the participations.

The final data analysis consisted of two main steps to come with the results. These two steps are required to test the model and the hypotheses. The first step is measurement model. The second step is structural model (Hair, Sarstedt, Hopkins, \& Kuppelwieser, 2014).

\subsection{Assessment of Measurement Model}

The determination of how the constructs are evaluated and measured is in the measurement model assessment (Hair, Hult, Ringle, \& Sarstedt, 2014). To assess the measurement model, many tests used to evaluate the internal consistency and evaluate the convergent validity. Also, should see the results of average variance extracted (AVE). Based on the findings of (Hair et al., 2014). Tables 6-8 will summarize all standards of each test to conduct the assessment of measurement model. Also, Figure 7 shows the results of measurement model.

\subsection{Measurement of Structural Model}

Assessment of structural model is the next stage after it has been confirmed that all constructs measures are reliable and valid. This study will evaluate the significance and relevance of the structural model. This stage can be done by assessment of the path coefficients ( $P$ value) and the calculation of error (T value) and both values can be found by means of bootstrapping. Table 9 present Criteria of Structural Model Assessment. 


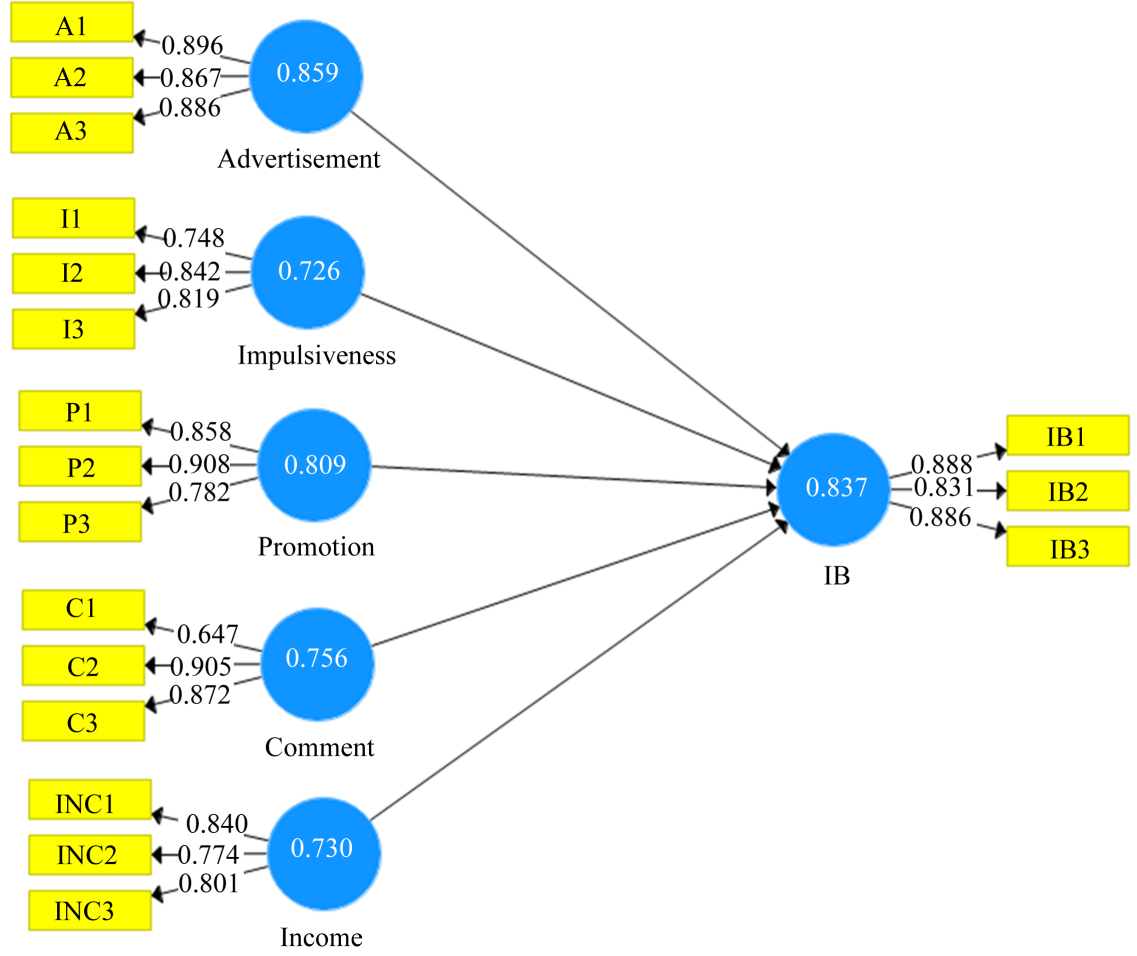

Figure 7. Measurement model results.

Table 5. Summarize of respondents demographics.

\begin{tabular}{cccc}
\hline Demographics & Categories & Frequency & Percentage \\
\hline \multirow{2}{*}{ Gender } & Male & 55 & $18.1 \%$ \\
& Female & 235 & $81.9 \%$ \\
\hline \multirow{2}{*}{ Age } & $20-24$ & 11 & $6.3 \%$ \\
& $25-34$ & 76 & $22.5 \%$ \\
& $35-44$ & 111 & $38.6 \%$ \\
& Above 44 & 92 & $32.6 \%$ \\
\hline \multirow{2}{*}{ Income } & Under 5000 & 87 & $33 \%$ \\
& $5000-14,000$ & 121 & $41 \%$ \\
& $15,000-24,000$ & 65 & $20.9 \%$ \\
& Above 25,000 & 17 & $5.1 \%$ \\
\hline
\end{tabular}

Table 6. Criteria of measurement model assessment.

\begin{tabular}{ccc}
\hline Types of Analysis & Test name & Stander Criteria \\
\hline \multirow{2}{*}{ Internal Consistency Reliability } & Cronbach's Alpha & $\geq 0.6$ Acceptable \\
& Composite reliability & $\geq 0.6$ Acceptable \\
\hline Convergent Validity & Factor loading & $\geq 0.7$ Acceptable \\
& AVE $\geq 0.5$ Acceptable & $\geq 0.5$ Acceptable \\
\hline
\end{tabular}


Table 7. Internal consistency reliability.

\begin{tabular}{ccc}
\hline \multirow{2}{*}{ Construct Name } & \multicolumn{2}{c}{ Internal Consistency Reliability } \\
\cline { 2 - 3 } & Cronbach's Alpha & Composite Reliability \\
\hline Advertisement & 0.859 & 0.914 \\
Comment & 0.756 & 0.854 \\
Impulsiveness & 0.726 & 0.846 \\
impulse Buying & 0.837 & 0.902 \\
Promotion & 0.809 & 0.887 \\
Income & 0.730 & 0.847 \\
\hline
\end{tabular}

Table 8. Convergent validity results based on outer loading and AVE.

\begin{tabular}{|c|c|c|c|}
\hline \multirow[t]{2}{*}{ Construct name } & \multirow[t]{2}{*}{ AVE } & \multicolumn{2}{|c|}{ Outer loading } \\
\hline & & $\mathrm{A} 1$ & 0.896 \\
\hline \multirow[t]{3}{*}{ Advertisement } & 0.780 & $\mathrm{~A} 2$ & 0.867 \\
\hline & & $\mathrm{A} 3$ & 0.886 \\
\hline & & $\mathrm{C} 1$ & 0.647 \\
\hline \multirow[t]{3}{*}{ Comment } & 0.666 & $\mathrm{C} 2$ & 0.905 \\
\hline & & $\mathrm{C} 3$ & 0.872 \\
\hline & & I1 & 0.748 \\
\hline \multirow[t]{3}{*}{ Impulsiveness } & 0.647 & I2 & 0.842 \\
\hline & & I3 & 0.819 \\
\hline & & IB1 & 0.888 \\
\hline \multirow[t]{3}{*}{ Impulse buying } & 0.755 & IB2 & 0.831 \\
\hline & & IB3 & 0.886 \\
\hline & & $\mathrm{P} 1$ & 0.858 \\
\hline \multirow[t]{3}{*}{ Promotion } & 0.724 & $\mathrm{P} 2$ & 0.908 \\
\hline & & P3 & 0.782 \\
\hline & & INC1 & 0.840 \\
\hline \multirow[t]{2}{*}{ Income } & 0.648 & INC2 & 0.774 \\
\hline & & INC3 & 0.801 \\
\hline
\end{tabular}

Table 9. Criteria of structural model assessment.

\begin{tabular}{lll}
\hline Types of Analysis & Test name & \multicolumn{1}{c}{ Stander Criteria } \\
\hline & & $*<0.10$ \\
& $P$ value & ${ }^{* *}<0.05$ \\
Path Relationship & & $* \star * 0.01$ \\
& & $>1.28$ level of significant $=10 \%$ \\
& T value & $>1.96$ level of significant $=5 \%>2.33$ level of \\
& & significant $=1 \%$ \\
\hline
\end{tabular}

\subsection{Structural Model Path Assessment}

Path assessment follows the collinearity assessment. Path coefficient aims to examine the hypothesized relationships between constructs in the structural 
model (Hair et al., 2014). Study found that the standard for path coefficient value is between -1 and +1 . If the path coefficient is close to +1 , it means there is a strong relation between constructs and that this relation is statistically significant. On the other hand, if the value is close to 0 , it means the relationship is very weak and considered not significant statistically. This study used one-tailed test, because all of the hypothesis relationships are directional and all hypotheses expected to be positive. There are critical values for one tailed based on (Hair et al., 2014) which are 1.28 is significant and significant level is $10 \%, 1.65$ is significant relationship and significant level is $5 \%$ and 2.33 is significant and significant level is $1 \%$. The T values and $P$ values were obtained by using bootstrapping from Smart PLS. Figure 8 shows the results of path coefficient as presented by using Smart PLS v3.

\subsection{Test of Hypotheses}

This section will discuss the result of the relationship between the constructs. This study has 5 hypotheses. The results from the bootstrapping test show that 3 out of 5 hypotheses were significant. The results of study hypothesis will show in the next Table 10.

To summarize the hypothesis relationship, the final results showed that consumers' impulsiveness, advertisement and promotion have a positive effect on Impulse buying in B2C e-commerce for Saudi Arabia. However, the income and comment do not have any effect on impulse buying because the constructs do not achieve the required value. Table 11 presents a summary of hypothesis results.

These results indicate that IB factors have positive effect on impulse buying in B2C e-commerce for Saudi Arabia. Figure 9 shows the final IB model.

Table 10. Hypotheses testing results.

\begin{tabular}{|c|c|c|}
\hline Hypothesis & Description of result & Final result \\
\hline $\begin{array}{l}\text { Consumers' impulsiveness } \\
\text { has positive impact in } \\
\text { impulse buying in } \\
\text { e-commerce. }\end{array}$ & $\begin{array}{l}\text { In the present study, the model shows a significant } \\
\text { effect of Consumers' impulsiveness on impulse } \\
\text { buying in e-commerce for Saudi Arabia } \\
\text { ( } \mathrm{t} \text { value }=8.125, p \text { value }=0.000 \text { ) the result } \\
\text { indicates that Consumers' impulsiveness is } \\
\text { positively related to Impulse buying. }\end{array}$ & supported \\
\hline $\begin{array}{l}\text { Advertisement has positive } \\
\text { impact in impulse buying } \\
\text { in e-commerce. }\end{array}$ & $\begin{array}{l}\text { This study model supported this hypothesis. } \\
\text { The results show the positive relationship } \\
\text { between Advertisement and Impulse buying } \\
\text { (t value }=5.093, p \text { value }=0.000)\end{array}$ & supported \\
\hline $\begin{array}{l}\text { Promotion has positive } \\
\text { impact in impulse buying } \\
\text { in e-commerce. }\end{array}$ & $\begin{array}{l}\text { The results of this study show the positive effect } \\
\text { of Promotion on Impulse buying } \\
\text { (t value }=1.783, p \text { value }=0.038 \text { ) }\end{array}$ & supported \\
\hline $\begin{array}{l}\text { Income has positive } \\
\text { impact in impulse } \\
\text { buying in e-commerce. }\end{array}$ & $\begin{array}{l}\text { This study model shows positive effect but the } \\
\text { results show negative effect Income on Impulse } \\
\text { buying ( } \mathrm{t} \text { value }=0.713, p \text { value }=0.238 \text { ). }\end{array}$ & $\begin{array}{c}\text { Not } \\
\text { supported }\end{array}$ \\
\hline $\begin{array}{l}\text { Comment has positive } \\
\text { impact in impulse buying } \\
\text { in e-commerce. }\end{array}$ & $\begin{array}{l}\text { This study model shows positive effect but the } \\
\text { results show negative effect of Comment on } \\
\text { Impulse buying ( } \mathrm{t} \text { value }=1.272, p \text { value }=0.102 \text { ). }\end{array}$ & $\begin{array}{c}\text { Not } \\
\text { supported }\end{array}$ \\
\hline
\end{tabular}




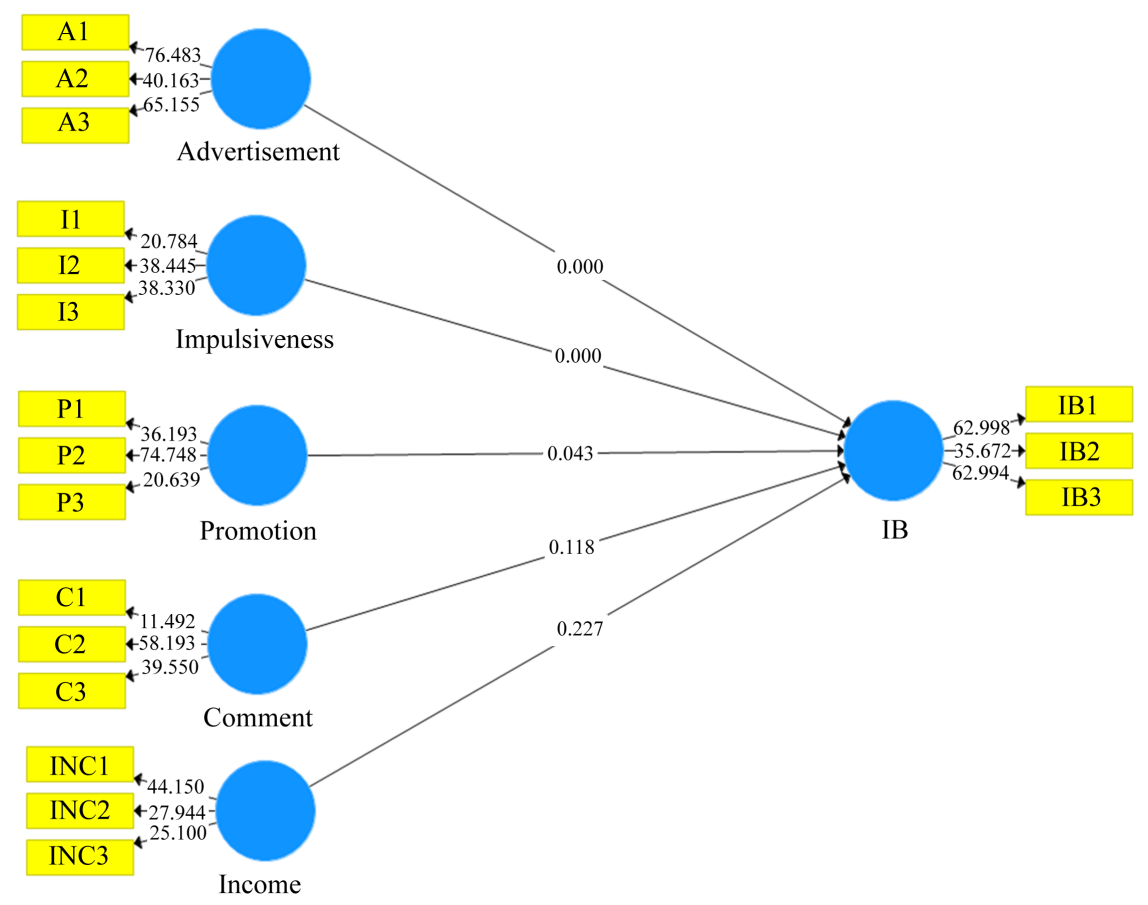

Figure 8. Path coefficient of structural model.

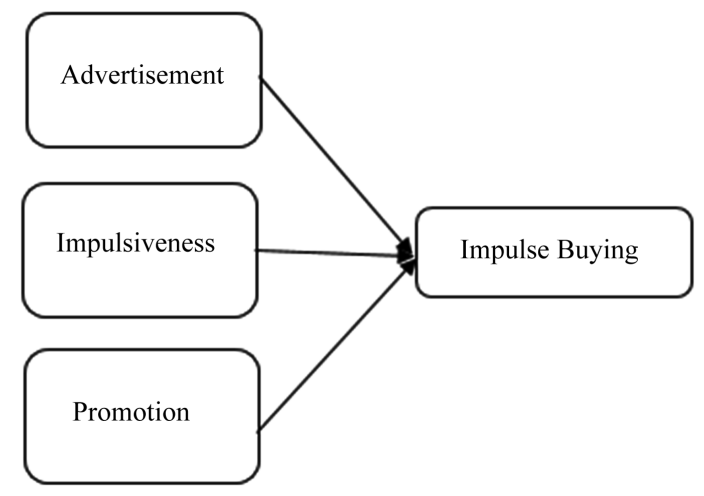

Figure 9. Final IB model for B2C E-commerce.

Table 11. Evaluation of research hypothesis.

\begin{tabular}{cccc}
\hline Path & T value & $P$ value & Significant level \\
\hline Advertisement $\rightarrow$ IB & 5.093 & 0.000 & $* * *$ \\
Comment $\rightarrow$ IB & 1.272 & 0.102 & ns \\
Impulsiveness $\rightarrow$ IB & 8.125 & 0.000 & $* * *$ \\
Income $\rightarrow$ IB & 0.713 & 0.238 & ns \\
Promotion $\rightarrow$ IB & 1.783 & 0.038 & $* *$ \\
\hline
\end{tabular}

\section{Conclusion}

The main aim of this study was to find the IB factors for B2C in Saudi Arabia to increase the shopping online revenue develop the IB for B2C e-commerce model and finally evaluate the proposed model. In the first stage, the author tried to 
find the most factors influence the IB for $\mathrm{B} 2 \mathrm{C}$ from the previous literature. Then, made filtering for factors based on many criteria. Finally, the author developed the model based on selected factors. The study applied a quantitative approach to achieve the proposed research objectives. This study is aimed at finding the IB factors for B2C e-commerce in Saudi Arabia. Consequently, the study did not consider investigating other indicators that influence IB for B2C in Saudi Arabia. The respondents of this study are familiar with online shopping and definition of the IB but most of them have little knowing about the roles of IB in influencing consumers shopping manners, as the result the feedback from the questionnaire may be affected. Besides that, almost more than $80 \%$ of the respondents are female which leads to result that are more related to female than male. There are some opportunities for future research in this domain. First, this study uses the IB factors for B2C e-commerce. This can support the B2C e-commerce users to identify more factors that influence online shoppers to buy. This study found the IB factors for $\mathrm{B} 2 \mathrm{C}$ e-commerce, future work can be done in $\mathrm{B} 2 \mathrm{~B}$ or $\mathrm{C} 2 \mathrm{~B}$ e-commerce.

\section{Conflicts of Interest}

The authors declare no conflicts of interest regarding the publication of this paper.

\section{References}

Abayi, M., \& Khoshtinat, B. (2016). Study of the Impact of Advertising on Online Shopping Tendency for Airline Tickets by Considering Motivational Factors and Emotional Factors. Procedia Economics and Finance, 36, 532-539. https://doi.org/10.1016/S2212-5671(16)30065-X

Abumalloh, R. A., Ibrahim, O., \& Nilashi, M. (2020). Loyalty of Young Female Arabic Customers towards Recommendation Agents: A New Model for B2C E-Commerce. Technology in Society, 61, Article ID: 101253. https://doi.org/10.1016/j.techsoc.2020.101253

Akram, U., Hui, P., Khan, M. K., Saduzai, S. K., Akram, Z., \& Bhati, M. H. (2017). The Plight of Humanity: Online Impulse Shopping in China. Human Systems Management, 36, 73-90. https://doi.org/10.3233/HSM-171768

Alshehri, H. A. D. (2015). A Framework for the Implement of B2C E-Commerce in Saudi Arabia: A Comparative Study of Saudi Living in Saudi Arabia and Those Living in UK, and the Perception of Saudi Companies. PhD Thesis, Salford: University of Salford.

Altaf, M., Shamim, A., Yousaf, U., \& Ghazali, Z. (2013). Customer Relationship Satisfaction and Relationship Improvement: Key Determinants of Customer Loyalty. International Journal of Marketing Principles and Practices, 3, 6-12.

Amiri, F., Jasour, J., Shirpour, M., \& Alizadeh, T. (2012). Evaluation of Effective Fashionism Involvement Factors Effects on Impulse Buying of Customers and Condition of Interrelation between These Factors. Journal of Basic Sciences and Applied Research, 2, 9413-9419.

Awan, A. G., \& Abbas, N. (2015). Impact of Demographic Factors on Impulse Buying Behavior of Consumers in Multan-Pakistan. European Journal of Business and Management, 7, 96-105. 
Beatty, S. E., \& Ferrell, M. E. (1987). Impulse Buying: Modeling Its Precursors. Journal of Retailing, 74, 169-191. https://doi.org/10.1016/S0022-4359(99)80092-X

Britannica (2020). E-Commarce. https://www.britannica.com/technology/e-commerce

Chang, H. J., Eckman, M., \& Yan, R. N. (2011). Application of the Stimulus-Organism-Response Model to the Retail Environment: The Role of Hedonic Motivation in Impulse Buying Behavior. The International Review of Retail, Distribution and Consumer Research, 21, 233-249. https://doi.org/10.1080/09593969.2011.578798

Chen, H. (2012). The Impact of Comments and Recommendation System on Online Shopper Buying Behaviour. Journal of Network, 7, 345-350.

Chen, H., \& Li, Z. (2009). A Qualitative Research to Classifying Comments in Online Shops Based on Contents. 2009 International Conference on Management and Service Science, Beijing, 20-22 September 2009, 1-5.

https://doi.org/10.1109/ICMSS.2009.5303900

Chen, J., Jin, Q., Zhao, S., Bao, S., Zhang, L., Su, Z., \& Yu, Y. (2014). Does Product Recommendation Meet its Waterloo in Unexplored Categories? No, Price Comes to Help. Proceedings of the 37th International ACM SIGIR Conference on Research and Development in Information Retrieval, Gold Coast, July 2014, 667-676.

https://doi.org/10.1145/2600428.2609608

Chen, Y., \& Wang, R. (2016). Are Humans Rational ? Exploring Factors Influencing Impulse Buying Intention and Continuous Impulse Buying Intention. Journal of Consumer Behaviour, 197, 186-197. https://doi.org/10.1002/cb.1563

Choudhary, S. (2014). Study of Impulse Buying Behavior of Consumers. International Journal of Advance Research in Computer Science and Management Studies, 2, 1-4.

Veena Parboteeah, D. (2009). The Influence of Website Characteristics on a Consumer's Urge to Buy Impulsively. Information Systems Research, 20, 60-78.

https://doi.org/10.1287/isre.1070.0157

Dattalo, P. (2008). Determining Sample Size: Balancing Power, Precision, and Practicality. New York, NY: Oxfrod University Press. https://doi.org/10.1093/acprof:oso/9780195315493.001.0001

Dawson, S., \& Kim, M. (2009). External and Internal Trigger Cues of Impulse Buying Online. Direct Marketing, 3, 20-34. https://doi.org/10.1108/17505930910945714

DeMatas, D. (2019). Types of Ecommerce Business Models That Work Right Now. Pridobljeno, 4, 5-17.

Hair Jr., J. F., Sarstedt, M., Hopkins, L., \& Kuppelwieser, V. G. (2014). Partial Least Squares Structural Equation Modeling (PLS-SEM) An Emerging Tool in Business Research. European Business Review, 26, 106-121. https://doi.org/10.1108/EBR-10-2013-0128

Hair Jr., J., Hult, T., Ringle, C., \& Sarstedt, M. (2014). A Primer on Partial Least Squares Structural Equation Modeling (PLS-SEM). Thousand Oaks, CA: SAGE.

Harmancioglu, N., Finney, R. Z., \& Joseph, M. (2009). Impulse Purchases of New Products: An Empirical Analysis. Journal of Product and Brand Management, 18, 27-37. https://www.emerald.com/insight/publication/issn/1061-0421

Hosseini, S. H., Zadeh, F. H., Shafiee, M. M., \& Hajipour, E. (2020). The Effect of Price Promotions on Impulse Buying: The Mediating Role of Service Innovation in Fast Moving Consumer Goods. International Journal of Business Information Systems, 33, 320-336. https://doi.org/10.1504/IJBIS.2020.105828

Jyoti, A., \& Verma, A. (2015). Does Urge to Buy Impulsively Differ from Impulsive Buying Behaviour? Assessing the Impact of Situational Factors. Journal of Retailing and 
Consumer Services, 22, 145-157. https://doi.org/10.1016/j.jretconser.2014.10.002

Karbasivar, A., \& Yarahmadi, H. (2011). Evaluating Effective Factors on Consumer Impulse Buying Behavior. Asian Journal of Business Management, 2, 174-181.

Kem Z.K. Zhang, Xu, H., Zhao, S., \& Yugang Yu. (2018). Online Reviews and Impulse Buying Behavior: The Role of Browsing and Impulsiveness. Internet Research, 28, 522-543. https://doi.org/10.1108/IntR-12-2016-0377

Niazi, G., Siddiqui, J., Shah, B., \& Hunjra, A. (2012). Effective Advertising and Its Influence on Consumer Buying Behavior. Information Management and Business Review, 4, 114-119. https://doi.org/10.22610/imbr.v4i3.971

Kim, J. (2003). College Students' Apparel Impulse Buying Behaviors in Relation to Visual Merchandising. Master's Thesis, Athens: University of Georgia.

Koski, N. (2012). Impulse Buying on the Internet: Consumer Experiences. Management, 5, 25-36.

Kotler, P., Keller, K. L., Brady, M., Goodman, M., \& Hansen, T. (2012). Marketing Management (2nd European ed.). Harlow: Pearson.

Liao, S. L., Shen, Y. C., \& Chu, C. H. (2009). The Effects of Sales Promotion Strategy, Product Appeal and Consumer Traits on Reminder Impulse Buying Behaviour. International Journal of Consumer Studies, 33, 274-284.

https://doi.org/10.1111/j.1470-6431.2009.00770.x

Makki, E., \& Chang, L. C. (2014). E-Commerce in Saudi Arabia: Acceptance and Implementation Difficulties. In The 2014 International Conference on E-Learning, E-Business, Enterprise Information Systems, and E-Government (EEE'14) (pp. 114-120).

Malik, M. E., Ghafoor, M. M., \& Iqbal, H. K. (2013). Impact of Brand Image and Advertisement on Consumer Buying Behavior. World Applied Sciences Journal, 23, 117-122.

Mathur, S. (2019). A Review of Impulse Buying Behavior: Definition \& Affecting Factors. Journal of Emerging Technologies and Innovative Research, 6, 270-275

Merugu, P., \& Vaddadi, K. M. (2017). Visual Merchandising: (A Study on Consumer Impulsive Buying Behaviour in Greater Visakhapatnam City). International Journal of Engineering Technology Science and Research, 4, 915-927.

Mirescu, S. V. (2010). The Premises and the Evolution of Electronic Commerce. Journal of Knowledge Management, Economics and Information Technology, 1, 1-5.

Muruganantham, G., \& Bhakat, R. S. (2013). A Review of Impulse Buying Behavior. International Journal of Marketing Studies, 5, 149-160. https://doi.org/10.5539/ijms.v5n3p149

Nanehkaran, Y. A. (2013). An Introduction to Electronic Commerce. International Journal of Scientific \& Technology Research, 2, 190-193.

Nordea. (2021). E-Commerce in Saudi Arabia.

https://www.nordeatrade.com/en/explore-new-market/saudi-arabia/e-commerce

Rahman, M. N. (2015). Pitfalls of Impulse Purchase: A Case Study in Saudi Arabian Context. Global Journal of Management and Business Research: E Marketing, 15, 36-44.

Rahman, M. N. (2016). Pitfalls of Impulse Purchase: A Case Study in Saudi Arabian Context. Global Journal of Management and Business Research, 15, 37-41.

Rook, D. W. (1987). The Buying Impulse. Journal of Consumer Research, 14, 189-199. https://doi.org/10.1086/209105

Saad, M., \& Metawie, M. (2015). Store Environment, Personality Factors and Impulse Buying Behavior in Egypt: The Mediating roles of Shop Enjoyment and Impulse Buy- 
ing Tendencies. Journal of Business and Management Sciences, 3, 69-77.

Sharma, P., Sivakumaran, B., \& Marshall, R. (2009). Impulse Buying and Variety Seeking: A Trait-Correlates Perspective. Journal of Business Research, 63, 276-283. https://doi.org/10.1016/j.jbusres.2009.03.013

Statista. (2021). eCommerce in Saudi Arabia. https://www.statista.com/outlook/243/110/ecommerce/saudi-arabia

Stern, H. (1962). The Significance of Impulse Buying Today. Journal of Marketing, 26, 59-62. https://doi.org/10.2307/1248439

Taush, A. (2007). "Destructive Creation"? Some Long-Term Schumpeterian Reflections on the Lisbon Process. Germany: Entelequia.

Tinne, W. S. (2011). Factors Affecting Impulse Buying Behavior of Consumers at Superstores in Bangladesh. ASA University Review, 5, 209-220.

Urbach, N., \& Ahlemann, F. (2010). Structural Equation Modeling in Information Systems Research Using Partial Least Squares. Journal of Information Technology Theory and Application, 11, 5-40.

Wang, X., Tauni, M. Z., Zhang, Q., Ali, A., \& Ali, F. (2020). Does Buyer-Seller Personality Match Enhance Impulsive Buying? A Green Marketing Context. Journal of Marketing Theory and Practice, 28, 436-446. https://doi.org/10.1080/10696679.2020.1780137

Wells, J. D., Parboteeah, V., \& Valacich, J. S. (2018). Online Impulse Buying: Understanding the Interplay between Consumer Impulsiveness and Website Quality. Journal of the Association for Information Systems, 12, Article No. 3. https://doi.org/10.17705/1jais.00254

Wu, I. L., Chen, K. W., \& Chiu, M. L. (2016). Defining Key Drivers of Online Impulse Purchasing: A Perspective of Both Impulse Shoppers and System Users. International Journal of Information Management, 36, 284-296.

Yang, D.-J., Huang, K. C., \& Feng, X. (2011). A Study of the Factors that Affect the Impulsive Cosmetics Buying of Female Consumers in Kaohsiung. International Journal of Business and Social Science, 2, 275-282.

Yu, C., \& Bastin, M. (2010). Hedonic Shopping Value and Impulse Buying Behavior in Transitional Economies: A Symbiosis in the Mainland China Marketplace. Journal of Brand Management, 18, 105-114. https://doi.org/10.1057/bm.2010.32 